\title{
Taking the Temperature: Implications for Adoption of Election Day Registration, State-Level Voter Turnout, and Life Expectancy
}

\author{
A Wuffle, University of California, Irvine \\ Craig Leonard Brians, Virginia Tech \\ Kristine Coulter, University of California, Irvine
}

ABSTRACT We consider the neglected importance of temperature as an explanatory variable. We show that: (1) colder states have turnout that is high relative to the national average; (2) the coldest states in the United States were more likely to adopt Election Day Registration (EDR) than other states, and very hot states never did so; and (3) those who live in colder states live longer.

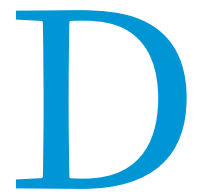

rawing on the insights of Nelson Polsby, Noël Coward, Nancy Mitford, Montesquieu, and Tatu Vanhanen, we argue for the importance of temperature as an explanatory variable. Nelson Polsby (1986) has largely credited air-conditioning with both the economic development of the South in the post-World War II period, and Florida's growth as the nation's retirement capital. Nancy Mitford, following up on intuitions of George Orwell in "Keep the Apsidistra Flying," has called attention to the peculiarities of Love in a Cold Climate (1949). And, of course, who can forget Noël Coward's legendary observation that only "mad dogs and Englishmen go out in the midday sun" (Coward 1931). Relatedly, Montesquieu observed long ago that liberal republicanism has yet to be successful in hot climates. Building on this insight, Vanhanen (2004) uses contemporary data to demonstrate that countries with high temperatures have low levels of democratization (a correlation between a nation's mean temperature and its

A Wuffle is associate to professor in the department of political science and the Institute for Mathematical Behavioral Sciences at the University of California, Irvine. His research has found broad exposure, if not acceptance, in the discipline since the early 1970s, with articles appearing in such journals as the Journal of Theoretical Politics, Simulation and Games, Mathematics Magazine, and PS: Political Science \& Politics. A Wuffle may be contacted \% Shani Brasier at sbraiser@uci.edu.

Craig Leonard Brians is associate professor and associate chair in the department of political science at Virginia Tech. He is the principal author of Empirical Political Analysis, 8th edition (Longman 2011), and may well use this article as a cautionary tale in an upcoming edition of this research methods text. His (actual) research has been published in the American Political Science Review, American Journal of Political Science, Public Choice, Journal of Political Science Education, and other journals. He can be reached at cbrians@vt.edu

Kristine Coulter is a doctoral student in the department of political science and a Fellow of the Center for the Study of Democracy at the University of California, Irvine. She may be contacted at kcoulter@uci.edu
Vanhanen index of democracy of - .57) - a fact which, if fully appreciated, might have countered US efforts to impose democracy on Iraq during the 2000s. ${ }^{2}$

The particular focus of our present research is on the relationship between temperature and political participation. Here, we look at the relationship between temperature and voter turnout in the United States, and between temperature and the decision to adopt Election Day Registration (EDR). In addition, we offer a new and intriguing empirical finding about the link between temperature and longevity that nicely complements earlier work on longevity-inducing features of holding high political office (Wuffle, Brunell, and Koetzle 1997).

\section{TEMPERATURE AND TURNOUT}

The National Voter Registration Act of 1993 (NVRA) mandated states' adoption of measures to make registration easier. ${ }^{3}$ Although not incorporated into the NVRA's focus on motor voter and agencybased registration procedures, EDR may be seen as lowering citizens' turnout barriers more than any other reform because it permits both registration and turnout at the apex of the political campaign on election day (Brians and Grofman 1999; Brians and Grofman 2001). We may identify three different "waves" of EDR adoption, the first before and the next two after the passage of the NVRA. "Wave 1" states adopted EDR prior to the 1976 presidential election. "Wave 2" came into play in the 1996 election, while "Wave 3 " occurred just before the 2008 election.

Table 1 shows 2004 turnout levels of states with and without EDR. In summarizing the findings of table 1, a political scientist might conclude that (1) EDR leads to higher turnout, and (2) states in the North are more likely to adopt EDR.

The direct inspiration for this article comes from an observation by students in the second author's freshman US government 
Table 1

Voter Turnout and Voter Registration Laws in 2004

\begin{tabular}{|c|c|c|c|c|c|}
\hline State & 2004 VAP Turnout & Voter Registration Rule & State & 2004 VAP Turnout & Voter Registration Rule \\
\hline Minnesota & 75.1 & EDR Wave 1 & Kentucky & 59.0 & NVRA \\
\hline Wisconsin & 72.6 & EDR Wave 1 & Maryland & 59.0 & NVRA \\
\hline Maine & 72.5 & EDR Wave 1 & Florida & 57.9 & NVRA \\
\hline Alaska & 69.3 & NVRA & Utah & 57.0 & NVRA \\
\hline New Hampshire & 69.0 & EDR Wave 2 & Illinois & 56.7 & NVRA \\
\hline South Dakota & 68.8 & NVRA & New Jersey & 56.3 & NVRA \\
\hline lowa & 68.1 & EDR Wave 3 & Oklahoma & 56.3 & NVRA \\
\hline Oregon & 67.4 & NVRA & Alabama & 56.2 & NVRA \\
\hline North Dakota & 67.1 & No Registration & North Carolina & 56.0 & NVRA \\
\hline Ohio & 66.5 & NVRA & Tennessee & 55.4 & NVRA \\
\hline Montana & 65.3 & EDR Wave 3 & Mississippi & 55.4 & NVRA \\
\hline Wyoming & 65.3 & EDR Wave 2 & New Mexico & 55.0 & NVRA \\
\hline Michigan & 64.9 & NVRA & Indiana & 54.4 & NVRA \\
\hline Vermont & 64.8 & NVRA & West Virginia & 54.2 & NVRA \\
\hline Missouri & 64.4 & NVRA & Rhode Island & 53.8 & NVRA \\
\hline Colorado & 62.7 & NVRA & South Carolina & 52.9 & NVRA \\
\hline Washington & 62.2 & NVRA & Arkansas & 52.5 & NVRA \\
\hline Pennsylvania & 61.7 & NVRA & District of Columbia & 52.3 & NVRA \\
\hline Delaware & 61.3 & NVRA & Georgia & 52.1 & NVRA \\
\hline Connecticut & 60.6 & NVRA & New York & 51.0 & NVRA \\
\hline Massachusetts & 60.2 & NVRA & Arizona & 48.8 & NVRA \\
\hline Nebraska & 60.1 & NVRA & Nevada & 48.8 & NVRA \\
\hline Idaho & 60.1 & EDR Wave 2 & California & 47.6 & NVRA \\
\hline Kansas & 59.7 & NVRA & Texas & 46.9 & NVRA \\
\hline Virginia & 59.6 & NVRA & Hawaii & 45.7 & NVRA \\
\hline Louisiana & 59.3 & NVRA & & & \\
\hline
\end{tabular}

Source: Aggregate, state-level turnout of the voting age population was computed from official state turnout data (Federal Election Commission 2005) and Census Bureau estimates of the Voting Age Population (Bureau of the Census 2004).

Note: This table uses VAP, because VEP is not available for individual states in 1972 (a comparison year used in other research [Brians 2011]). We use 2004 data to demonstrate that even before adopting EDR, lowa and Montana were high turnout states. VAP = voting age population; VEP = voting eligible population.

and politics course who, after eyeballing the data in table 1, suggested, on the one hand, that colder climates lead to higher turnout and, on the other hand, that colder states were especially likely to adopt EDR. In the first part of this article we statistically test the accuracy of each of these two claims.

We get an intuitive sense of the relationship between temperature and turnout by comparing figure 1 with figure 2 . The first map categorizes states by turnout level in 2004; the second map classifies states by their mean November temperature (averaged over two decades). ${ }^{6}$ Because we have selected map legend coding having a similar intensity scale, the continuity between the two maps is visually apparent: Those living in colder states are more likely to vote.

The scatter plot in figure 3 compares 2004 turnout with mean November temperature by state. The associated bivariate regression generates an adjusted $\mathrm{R}^{2}$ of .47 $(p=.00000002) .{ }^{7}$ It would appear that a three-point increase in mean temperature level (Fahrenheit) converts to about a one-point decrease in turnout.

\section{EXPLAINING THE ADOPTION OF EDR}

The nine states that adopted EDR in any of the three waves, or like North Dakota which has no voter registration requirement, average a 34.3 degree temperature in November, as compared to 48.8 degrees in the 41 other states and the District of Columbia. ${ }^{8}$ This 14 degree temperature difference is significant at the $p=.0001$ level. ${ }^{9}$ Moreover, none of the hottest states in the country has adopted EDR. Indeed, taking EDR adoption as the dummy dependent variable, and using just November temperature as the independent variable in a bivariate logistic regression, the result is statistically significant at the $p=.007$ level (with a Nagelkerke pseudo $\mathrm{R}^{2}$ of .57 ).

\section{THE THIRD WAVE OF EDR ADOPTION}

Building on Daryl Bem's (2011) seminal experimental evidence for the existence of ESP and precognition, one of our ancillary contributions is to show how states that had not yet adopted EDR in 2004, but were just about to (the Third Wave of EDR adoption) 
Figure 1

\section{Map of States' Voting Age Population Turnout in November 2004}

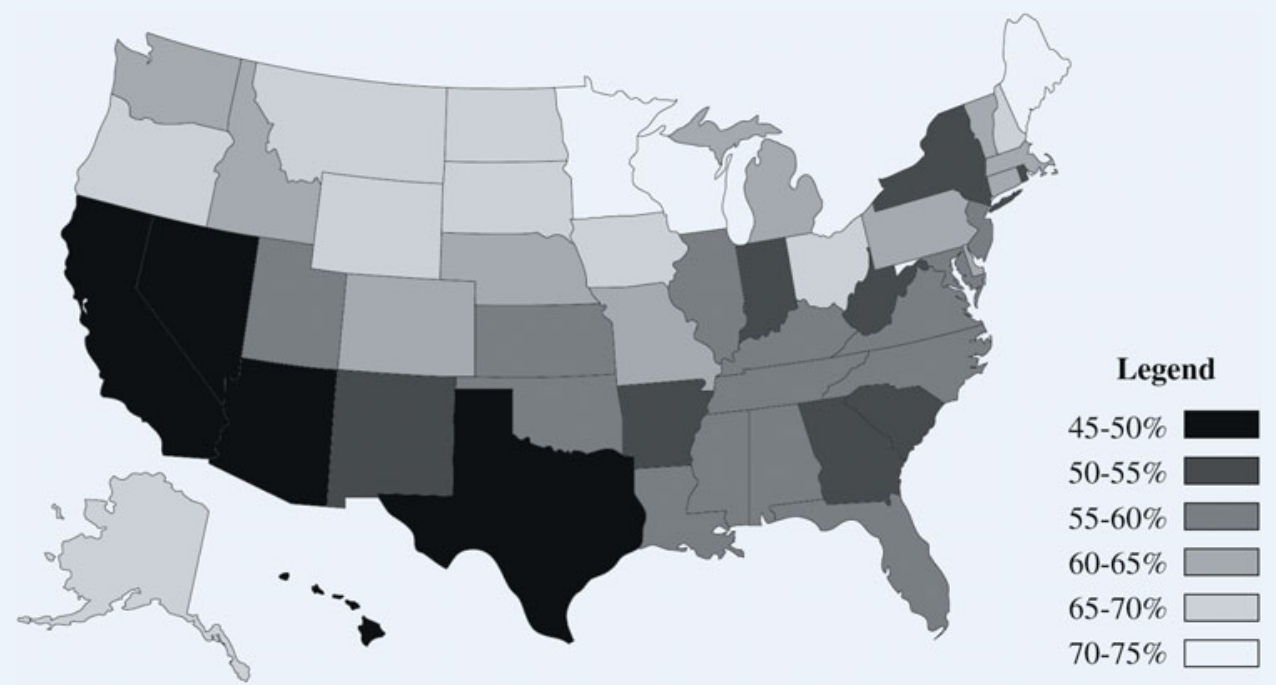

Source: Aggregate, state-level turnout of the voting age population was computed from official state turnout data (Federal Election Commission 2005) and Census Bureau estimates of the Voting Age Population (Bureau of the Census 2004).

THE EFFECT OF

\section{TEMPERATURE ON}

\section{LONGEVITY}

Having shown that temperature has a strong effect on voter turnout, it occurred to us to examine, in a similar fashion, the impact of temperature on other variables. Because we had handy a data set with state level life expectancy, we regressed that variable on state level temperature. To our delight (but not our surprise), we found a strong correlation, an adjusted $\mathrm{R}^{2}$ value of .40 ( $p=.000001)$, between life expectancy and temperature. For every five-degree (Fahrenheit) increase in a state's mean November temperature, life expectancy in the state was decreased by one year.

\section{DISCUSSION}

Our goal was to build on the insights of Montesquieu and others to show the importance of a long-neglected variable, temperature, and we believe we have succeeded in that goal. Our evidence is compelling: across US states, both voter turnout and life expectancy are higher in cold climates. Of course, the reader may be skeptical that temperature is the real explanatory factor for EDR adoption, or for high turnout, or for greater life expectancy. For example, Keillor (n.d.) has proposed that cultural factors linked to the number of Scandinavians in a state may determine political behavior. ${ }^{10}$ However, getting the causality straight is beyond the scope of the present essay; ${ }^{11}$ rather ours is the much more modest goal of conclusively demonstrating nonetheless behaved as if they already had. Looking at table 1, we see that, ca. 2004, all three of the Third Wave EDR states already had among the dozen highest turnout levels of any of the states, demonstrating conclusively that anticipation of future policy change to a more turnout-friendly institutional environment can raise a state's turnout level. Indeed, when we look at the high turnout levels in these same three states as early as 1972, we see clear evidence for an active type of political precognition at work, because it is hard to imagine how in 1972 citizens in these states could otherwise have anticipated that the state would be adopting EDR by 2008. the power of the temperature variable. ${ }^{12}$ -
Above 55
$50-55^{\circ}$
$45-50^{\circ}$
$40-45^{\circ}$
$35-40^{\circ}$

Below $35^{\circ}$
Source: These data were gathered in each state's capital, and obtained from the National Weather Service.

\section{NOTES}

We are indebted to the US Census Bureau and the Federal Election Commission for population and turnout data, to Clover Behrend-Gethard and Sue Ludeman for bibliographic assistance, and to John Ensch for preparation of figure 1 and figure 2. A Wuffle also wishes to acknowledge his special debt to the late Max Weber for stimulating him to think seriously about political science as a vacation. This research was, unfortunately, not supported by any grants from the National Science Foundation.

1. Coward's observation anticipates both the Foucaultian emphasis on madness and the even more recent renewal of interest in culturalist explanations, with economists studying topics such as democracy or economic growth now 


\section{Figure 3}

\section{State Level Turnout in 2004 versus Mean Temperature in November}

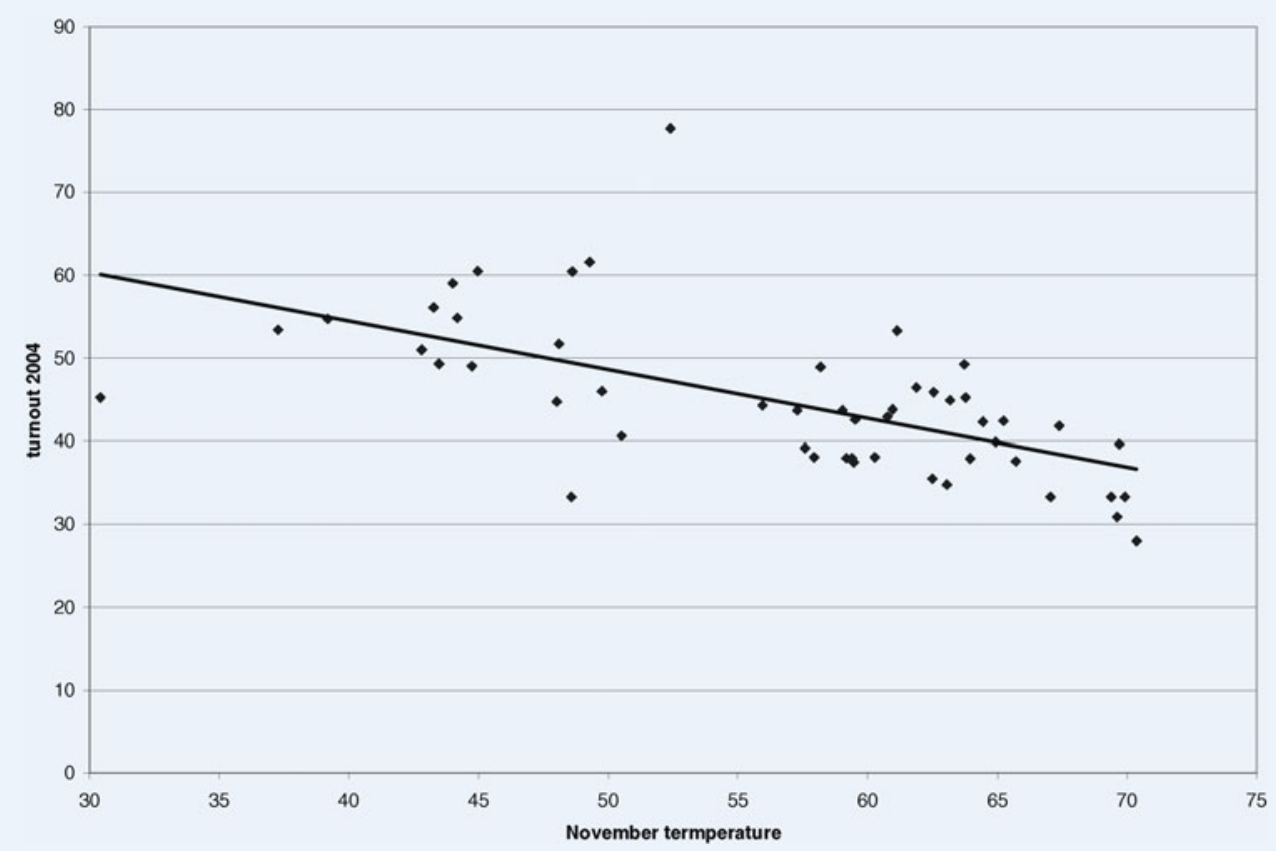

Source: Aggregate, state-level turnout of the voting age population was computed from official state turnout data (Federal Election Commission 2005) and Census Bureau estimates of the Voting Age Population (Bureau of the Census 2004), with temperature data gathered in each state's capital and obtained from the National Weather Service.

9. An ANOVA analysis indicated that the mean November temperatures in the states comprising the three waves of EDR do not statistically significantly differ from one another $(p=.6)$.

10. In other analyses we have demonstrated (data omitted due to limited space) that temperature at the state level is highly correlated both with racial composition of the state (cf. Alt 1994) and with Elazar's (1966) political culture index as recoded by Sharkansky (1969). Relatedly, we might note that one anonymous reviewer suggested that the correlation between temperature and death rate might be caused simply by people moving to warmer climes as they grow older (cf. the "elephant's graveyard" found in early Tarzan movies, where old elephants go to die).

We should note that other scholars (e g., Wainer 2005, 121) have also linked temperature in a state temperature to the state's homicide rate.

11. We also leave it to others to debate the positivist claim that causal laws of human behavior can, at least in principle, be ascertained.

12. The use of temperature as an independent variable raises issues of causality in other contexts as well, in terms of identifying mediating factors. For example, Vanhanen (Vanhanen 2009; Lynn and Vanhanen 2002) attributes the impact of temperature on democracy to

almost as likely to make use of the data from the World Values Survey as are political scientists (Inglehart 2011).

2. Until Vanhanen's seminal work, Montesquieu's views of the importance of climate for democracy had, we believe, been almost totally neglected in the burgeoning academic literature on democratization. The only exception we have been able to find is Thomas L. Pangle's observation (1973: 167) that "The evidence of history would seem to lend some support to Montesquieu's views [that democracy required a temperate climate]." But Pangle is a political theorist, and hence his remarks may not have been taken seriously by men of affairs, or simply overlooked by more empirically minded political scientists. We should also note that the first author's own seminal 1980s work showing that democracy was especially unlikely in countries with high temperatures in their capitals (e.g., Iraq), which anticipated Vanhanen's work by around a decade, had its impact on the study of democracy limited by the fact that it was never submitted for publication ( $c f$ : "Articles not submitted for publication are unlikely to be published" Wuffle 1989).

3. Lower voter turnout in the United States., versus most other industrialized democracies, has been frequently attributed to more restrictive, state-specific voter registration rules in the United States (e.g., Rosenstone and Wolfinger 1978; Wolfinger and Rosenstone 1980; Powell 1986; Jackman 1987). For more skeptical views on the importance of registration as a barrier to turnout see Wattenberg (2002: cf. Gerber and Green 2004; Hanmer 2009).

4. One of the Wave 1 states dropped EDR during Summer 2011. Given this article's theory, it should be no surprise that the bill to repeal EDR was signed by Maine's Governor on June 21, 2011, the first day of summer, during the second warmest month of the year (Russell 2011a; National Weather Service 2011).

In a related development, a referendum to repeal the EDR repeal law qualified for the ballot in Maine's November 8, 2011 election (Russell 2011b). Given that this election occurred during a much cooler month, we would expect that the referendum would reverse the summer EDR repeal. As predicted, the final vote overwhelmingly restored EDR in Maine (Russell 2011c).

5. Very similar results would have been manifest regardless of the year selected in the post-World War II period.

6. These data were gathered in each state's capital, and obtained from the National Weather Service.

7. Delaware (moderate temperature, high turnout) is the only clear outlier.

8. North Dakota had voter registration until 1951, when it was abolished, except for in the city of Medora (North Dakota Secretary of State 2008). the intermediating link between temperature and IQ. The key hypothesis is that democracy is only for smart people, and Vanhanen and his co-author offer compelling evidence that the mean IQ of people in hot countries is lower than that of the inhabitants of colder climes. However, while we would emphasize that all the data reported in this article are real, there is, nonetheless, one key difference between the work of Vanhanen and his co-author and that of the present authors. The former intend their work to be taken seriously.

\section{REF ERENCES}

Alt, James. 1994. "The Impact of the Voting Rights Act on Black and White Voter Registration in the South." In Quiet Revolution in the South: The Impact of the Voting Rights Act, 1965-1990, ed. Chandler Davidson and Bernard Grofman, 351-77. Princeton, NJ: Princeton University Press.

Bem, Daryl J. 2011. "Feeling the Future: Experimental Evidence for Anomalous Retroactive Influences on Cognition and Affect." Journal of Personality and Social Psychology 100 (March): 407-25.

Brians, Craig Leonard. 2011. "The State Matters: Election Day Registration in the 7os, 9os and Today." Invited talk at the Center for Political Studies, University of Michigan (November 9).

Brians, Craig Leonard, and Bernard Grofman. 1999. "When Registration Barriers Fall, Who Votes? An Empirical Test of a Rational Choice Model.” Public Choice 99 (April): 161-76.

Brians, Craig Leonard, and Bernard Grofman. 2001. "Election Day Registration's Effect on U.S. Voter Turnout." Social Science Quarterly 82 (March): 170-83.

Colomer, Josep. 2004a. "It's Parties that Choose Electoral Systems (or, Duverger's Laws Upside Down)." In Handbook of Electoral Design, ed. J. Colmer. London: Palgrave.

Colomer, Josep. 2004b. "The Strategy and History of Electoral System Choice." In Handbook of Electoral Design, ed. J. Colomer. London: Palgrave.

Coward, Noël Peirce. 1931. "Mad Dogs and Englishmen.” A song. www.traditionalmusic.co.uk

Elazar, Daniel J. 1966. American Federalism: A View from the States. New York: Thomas Y. Crowell.

Federal Election Commission. 2005. Election Results for the U.S. President, the U.S. Senate and the U.S. House of Representatives. Washington, DC: Federal Election Commission (May). http://www.fec.gov/pubrec/fe2004/ federalelections2004.pdf 
Gerber, Alan S., and Donald P. Green. 2004. Get Out the Vote! How to Increase Voter Turnout. Washington, DC: Brookings Institution Press.

Hanmer, Michael J. 2009. Discount Voting: Voter Registration Reforms and Their Effects. New York and London: Cambridge University Press.

Inglehart, Ronald J. 2011. Personal communication with Bernard Grofman.

Jackman, Robert W. 1987. "Political Institutions and Voter Turnout in Industrial Democracies." American Political Science Review 81: 405-23.

Keillor, Garrison. n.d. "The Prairie Home Companion.” National Public Radio, on Sunday afternoons in southern California.

Lynn, Richard, and Tatu Vanhanen. 2002. IQ and the Wealth of Nations. Westport, CT: Praeger.

Mitford, Nancy. 1949. Love in a Cold Climate: A Novel. London: H. Hamilton.

Montesquieu, Charles de Secondat, Baron de. 1973 (translated and reprinted). The Spirit of Laws. Edinburgh: Silvester Doig.

National Voter Registration Act of 1993. 1993. Public Law 103-31 (May 20).

National Weather Service. 2011. "National Weather Service Climate Data for Portland, Maine, 1941-2010.” Accessed September 9 from www.erh.noaa.gov/er/ gyx/climate_f6.shtml

North Dakota Secretary of State. 2008. "North Dakota ... The Only State without Voter Registration." Retrieved July 22, 2008 from: www.nd.gov/sos/forms/pdf/ votereg.pdf

Pangle, Thomas L. 1973. Montesquieu's Philosophy of Liberalism. Chicago: The University of Chicago Press.

Polsby, Nelson. 1986. Personal communication with Bernard Grofman.

Powell, G. Bingham, Jr. 1986. "American Voter Turnout in Comparative Perspective.” American Political Science Review 80: 17-43.
Rosenstone, Steven J. and Raymond E. Wolfinger. 1978. "The Effect of Registration Laws on Voter Turnout." The American Political Science Review 72: 22-45.

Russell, Eric. 2011a. "LePage Signs Bill Banning Same-day Voter Registration, but Critics Vow to Fight." Bangor Daily News (June 21).

Russell, Eric. 2011b. "People's Veto of Same-day Voter Registration Ban Will be Question 1 in November." Bangor Daily News (September 8).

Russell, Eric. 2011c. "Mainers Vote to Continue Election Day Registration." Bangor Daily News (November 9).

Sharkansky, Ira. 1969. “The Utility of Elazar's Political Culture." Polity 2 (1): 66-83.

US Census Bureau. 2004. Voting and Registration in the Election of November 2004-Detailed Tables. Washington, DC: US Census Bureau (November). www.census.gov/hhes/www/socdemo/voting/publications/p20/2004/tables.html

Vanhanen, Tatu. 2004. "Climate and Democracy." Prepared for delivery at the 2004 Annual Meeting of the American Political Science Association, September 2-5.

Vanhanen, Tatu. 2009. The Limits of Democratization: Climate, Intelligence, and Resource Distribution. Atlanta, GA: Washington Summit Publishers.

Wainer, Howard. 2005. Graphic Discovery: A Trout in the Milk and Other Visual Adventures. Princeton, NJ: Princeton University Press

Wattenberg, Martin P. 2002. Where Have All the Voters Gone? Cambridge, MA: Harvard University Press.

Wolfinger, Raymond E., and Steven J. Rosenstone. 1980. Who Votes? New Haven, $\mathrm{CT}$ and London: Yale University Press.

Wuffle, A. 1989. "Uncle Wuffle's Advice to the Advanced Graduate Student." PS: Political Science \& Politics 22 (December): 838-39.

Wuffle, A, Thomas Brunell, and William Koetzle. 1997. "Death, Where Is Thy Sting? The Senate as a Ponce (de Leon) Scheme." PS: Political Science E Politics. 3o (March): 58-59. (Reprinted in the Journal of Irreproducible Results, 1999, 44 (5): 25-26.) 